\title{
ISLAMIC LEADERSHIP MOTIVATION IN MUHAMMADIYAH 3 WARU JUNIOR HIGHSCHOOL
}

\author{
Anik Isticharoh \\ Muhammadiyah University of Sidoarjo \\ Email: anik.smpm3@gmail.com
}

\begin{abstract}
Leadership is defined as a dynamic principle impetus that motivates and coordinates used by institutions in completing or achieving goals. Leadership captures the essentials of being able to inspire others and being prepared to do so. Teacher is also included in the leadership chain led by the principal. Teacher leadership is defined as a dynamic person that motivates and leads the classroom and also the institution for achieving leraning goals. This research uses descriptive method to explain data collection in the field, which provides an overview of the motivation of Islamic leadership obtained from observation. The approach in this study uses a qualitative approach. Data are written results from interviews in Mugaru Fest 2018 activities. Data sources are from teachers, vice principals, and principals. The results of this research appears in two kinds, positive motivation and inner-self motivation. The form of Islamic leadership motivation used in this research is a democratic model. There are several ways to increase the motivation of Islamic leadership as follows: respect, information, behavior, punishment, orders, and feelings.
\end{abstract}

Keywords: Motivation, Leadership, Islamic, Islamic Thought, Teachers, Vice Principal, Principal, Junior HighSchool.

\section{A. INTRODUCTION}

A school is an educational institution designed to provide learning spaces and learning environments for the teaching of students (or "pupils") under the direction of teachers. Most countries have systems of formal education, which is commonly compulsory. In these systems, student has progress through a series of schools. The names for these schools vary by country (discussed in the Regional section below) but generally include primary school for young children and secondary school for teenagers who have completed primary education. An institution where higher education being taught, is commonly called a university college or university, but these higher education institutions are usually not compulsory.

School is one form of institutional organization engaged in education. In the school it illustrates how to get continuity between school management and school residents, especially the teachers. Sardiman explains that the role of teachers in schools as employees (employees) in official relations, as subordinates (subordinate) to their superiors, as colleagues in relations with colleagues, as mediators in relation to students, as regulators, evaluators and substitutes for parents.

Education Minister also publishes a regulation in PERATURAN MENTERI PENDIDIKAN DAN KEBUDAYAAN REPUBLIK INDONESIA Number 23 Year 2017 article 1 number 3 about teacher regulation. It mentions that Teachers are professional educators with the main task of educating, teaching, guiding, directing, training, evaluating, and evaluating students in early childhood education, formal 
education, basic education, and secondary education. ${ }^{1}$

Therefore working as a teacher is a part of special profession that has scope as an educator, teacher, and trainer of students in an educational setting or environment. This is in line with the opinion expressed by Uzer Usman that the teaching profession includes educating, teaching, and training. Thus, the teacher has to do the duty and also becomes responsible in educating, teaching, and training students towards the direction of maturity by guiding all stages of student development (including cognitive, affective, and psychomotor aspects).

The teacher is also included in the leadership chain led by the principal. Leadership in Bass's opinion is defined as a dynamic principle impetus that motivates and coordinates the institution in completing or achieving goals. A leader must have an STAFF attitude (Shidiq, Tablig, Amanah, Fathonah). Those characteristics are also the characteristics of the Prophet Muhammad S.A.W. in line with Allah statement in $\mathrm{Al}$ Qur'an, namely:

Surah Al-Ahzab verse 21:

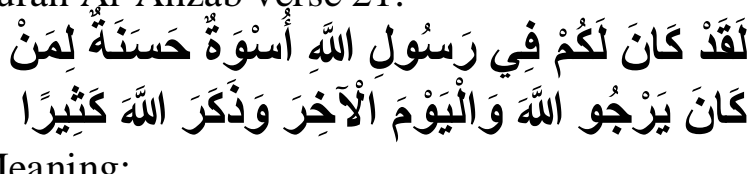

Meaning:

Surely there is in (the) Messenger of Allah a good example for you (that is) for those who wish (the mercy) of Allah and (the coming of) the Day of Judgment and he mentions Allah a lot.

Based on the statement above, the leadership has applied in the Muhammadiyah 3 Waru Junior HighSchool environment, is a part of Islamic leadership. Therefore, this study focuses on the various forms of Islamic leadership motivation that occurres in the Muhammadiyah 3 Waru Junior HighSchool environment.

\footnotetext{
${ }^{1}$ Hoy, Wayne. K and Cecil G. Miskel. 2013. Educational Administration: Theory, Research, and Practice. Mc Graw Hill.
}

\section{B. RESEARCH METHOD}

This research method uses descriptive method that has carried out through data collection in the field, which provides an overview of the motivation of Islamic leadership obtained from observation. Descriptive method according to Sugiyono (2013: 11) is a research method that aims to describe, explains the conditions that has exist in the company based on facts. The characteristics of the population is based on the data that has collected and then arranged systematically and subsequently analizing for conclusion.

This research approach uses a qualitative approach. Methods of qualitative research include observation and immersion, interviews, open-ended surveys, focus groups, content analysis of visual and textual materials, and oral history. The qualitative approach $^{2}$ typically is focused on the microlevel of social interaction that composes everyday life.

This qualitative research approach is employed across many academic disciplines, then followed by analyzing the forms of Islamic leadership motivation that occurs in Muhammadiyah 3 Waru Junior HighSchool.

This qualitative research approach is focusing particularly on the human elements of the social and natural sciences in learning academic.

This research data delivers in form of writing notes that has been transcribed from interviews result. Data are including word, phrases, and sentences.

The data source in this study comes from interviews result with Teachers, Vice Principals, and Principals in the Muhammadiyah 3 Waru Junior HighSchool. The interview has conducted at Mugaru Fest activities from December 2018 to January 2019.

\footnotetext{
2 Babbie, Earl (2014). The Basics of Social Research (6th ed.). Belmont, California: Wadsworth Cengage. pp. 303-304
} 


\section{RESEARCH RESULTS}

The leadership model is found in the form of democratic Islamic leadership, which occurs in Mugaru Fest activities from December 2018 to January 2019. The teachers are involved to show their leadership in guiding these activities to run smoothly.

This effort shows the motivation for Islamic leadership towards Muhammadiyah 3 Waru Junior HighSchool residents and also the events' participants who represents as assistants, guests' host, and participants in the Mugaru Fest competition.

The Islamic leadership motivation has shown the teachers of to have positive motivation and self-inner motivation. The positive motivation of the teachers is seen through a responsive event host by giving:

1) information on the location of activities,

2) attention in helping the activity committee,

3) work together during the activity,

4) participate in supervising activities,

5) and is responsible for maintaining school security and cleanliness.

Inner motivation ${ }^{3}$ arises in the teacher by carrying out the tasks in accordance to fulfill obligations in the Mugaru Fest 2018 event. In terms of having awareness that The teachers must not complain, compulsive, threat, or compensate in any case. This motivation always displays better discourses or actions such as high moral, deep discipline to do the task, to have better self confidence, and to have good arragement based on their task.

\section{RESEARCH DISCUSSIONS}

According to the statement that leadership is a capital, which must be owned by leaders who want to become a leader.

A leader has their own model in leading a group, community and organization, both formally and non-formally.

Basically the leadership model itself is divided into 5 leadership styles, namely
Autocratic, Militaryistic, Paternalistic, Charismatic, and Democratic. Yet, the most successful used by teachers at Muhammadiyah 3 Waru Junior HighSchool is Islamic democratic leadership.

Islamic democratic leadership provides the teachers ability of Muhammadiyah 3 Waru Junior HighSchool to influence other people to cooperate in achieving their stated goals as mutual agreement manner.

This evidence is to show the teachers' ability in controlling, regulating, and supervising in Mugaru Fest 2018 event process. As well as being the best companion that has initiative to held praying together before starting events and competitions, and becomes the best assistant in carrying out prayers in congregation along with the event participants to do Dhuhur and Ashar.

\section{Islamic Leadership}

Islamic leadership itself is a person or a group that will lead humanity from the brink of destruction to the way of Allah the Almighty. Importances of Islamic leadership are 1) every movement has a need for leadership; 2) similar to the engine of a train; 3 ) can solve the problems of humanity.

The differences between Islamic and secular leadership are 1) secular leadership target is self-establishment but Islamic leadership is Jannatul Firdaus; and 2) secular leadership works to give a respect to people but Islamic leadership is to respect and pleasure Allah.

\section{Teacher in Islam}

Teaching is one of the most respectful and valuable professions in the world. In religion Islam, this profession has more importance as our beloved Prophet Muhammad (SAW) introduced himself as a teacher. Allah Almighty says in Al-Quran, surah Al-Baqarah verse 151:

\footnotetext{
${ }^{3}$ Hakim, Abdul. 2007. Kepemimpinan Islami. Semarang: Unissula Press
} 


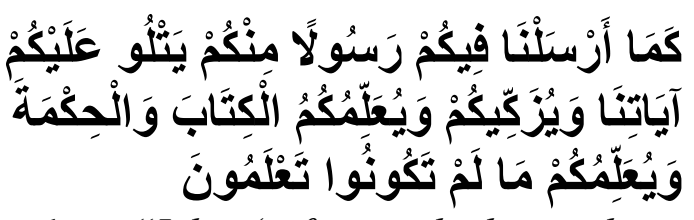

Means that: "Like (a favor which you have already received) in that We have sent among you a Messenger of your own, rehearsing to you Our verses, and purifying you, and instructing you in scripture and wisdom, and in new knowledge".

According to this verse of Holy Quran Holy Prophet (SAW) were sent to teach about the Holy Book Quran, the wisdom and unknown things to the people of this world.

Teachers are some of the most influential people in society and have great importance in modern society. Teachers bear the responsibility of molding students' personalities and educating them. Teachers are considered the most honored person in every religion. Due to the important role of teachers, Islam has granted high status and rights to teachers.

Islam has paid great attention to teachers for their being the first brick in the structure of social development and perfection and the cause of guiding and developing behaviors and mentalities of individuals and communities. We can understand the highest rank of teachers from the Quote of Hazrat Ali (RA) in which He (RA) stated that: "If $a$ person teaches me one single word, he has made me his servant for a lifetime."

The teacher is considered the profound father in religion Islam. All Prophets were the teacher that sent before Prophet Muhammad (SAW) and obviously, Holy Prophet (PBUH) was also the great teacher for all mankind. Prophet Muhammad (SAW) teaches us how to worship Allah, how to implement teachings of the Quran in our daily lives and many other things. Islam lays great emphasis on knowledge. At numerous times and instances, Allah Almighty ordered the Muslims to acquire knowledge and learn. Islam lays so much stress on seeking knowledge and also on giving the respect to the ones who imparted knowledge. That's why teachers have the highest status in Islam. In Al-Quran Almighty Allah says in

Al-Mujadilah verse 11:

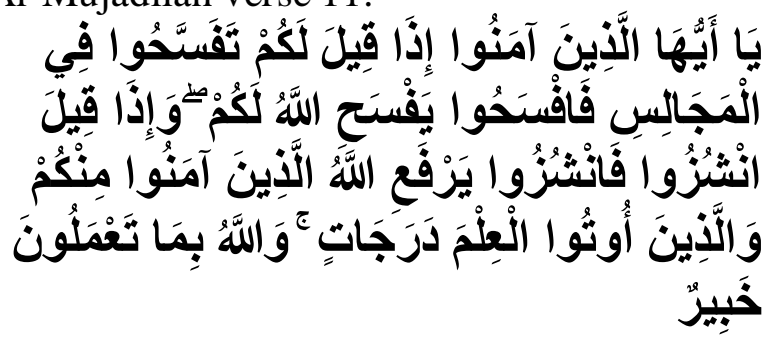

Means that: "Allah elevates to high positions those from amongst you who are faithful and those who have acquired knowledge".

Based on the verse above, a teacher can teach other person with some rights, which are mentioned below:

1) Lead his pupil means it's the duty of the teacher to make his student smarter and have a good Akhlaq.

2) Get reward and appreciation.

3) Teachers should have freedom of expression, obstacles and intervention should be cleared.

4) Teachers should get respect from other people.

5) Teachers should get good treatment to make his job easier.

6) Teachers should have freedom in giving judgment.

7) Teachers should acquire and utilize learning facilities and infrastructure.

8) Teachers should get physical and spiritual needs.

Therefore, we should know respect and become closer to the teacher who is willing to give us education and knowledge. So, being respectfull is an obligatory to a teacher.

\section{Leader}

A leader is an ideal worker and has primary assets of an ideal worker such as knowledge of Qur'an and Hadist; Iman or Faith; Taqwa or consciousness; A'mal or deeds; Salah or prayer; du'a or supplication; infaq or spending in the way of Allah; voluntary fasting; and others.

Besides, the basic qualities of an ideal worker are courageous; sincere; humane; 
organized; determined; hard-working; punctual; good conduct; good habit; and good in lecture and writing. Then, a leader also needs to improve his/her quality becoming more patience; wisdom; reliance on Allah; allegiance; and accountability.

Being a leader has a purpose, which is to deliver results through others, while some believe that the leaders' purpose is for developing more leaders.

Therefore, effective leaders hold themselves and other accountable to high standards for results and values, validate efforts and contributions, and ensure cooperative interaction and performance in a trusting, respectful work environment. Effective leaders do setting performance targets, demand cooperative interaction, validate efforts, celebrate accomplishments and team work, because they listen and learn to refine policies and procedures to make employee's jobs easier.

\section{Leader Motivation}

It means that a leader can lead someone else by motivating them to strive for certain goals rather than simply act on orders. The leader tries to create a safe and trusting environment, and ensure the organization is positioned for success in its domain.

Motivation can be done by doing communication with transparency, authenticity, and clarity. Then, motivation can transfer optimism and vision to others that inspire others to think and act in ways to drive results. Next, motivation also shares the vision, builds relationship, and creates purpose driven goals.

Being a motivational leader in Muhammadiyah 3 Waru Junior HighSchool needs a good qualified leader and a high motivation, especially to lead students who are lacking in Islamic knowledge and Islamic behaviour.

\section{Islamic Motivation}

Islamic motivation is needed for every Muslims in the world. Motivation itself can define as the desire within an individual that stimulates human to do an action. Motivation is the process to determine the intensity, direction, and the provisions of the individual's in achieving a goal or a target.

On the Islamic philosophy, the concept of motivation is unique compare to the conventional theories. That can be concluded as a term of desire, force, and direction is used in motivation as refer to the word motive. Motive or stimulus is defined as a reason to do something, which is caused or regarded a physiological or psychological response to achieve a certain purpose or objective.

Islamic motivation has divide into two parts. They are 1) primary and 2) secondary type of motivation. Primary motivation is called as basis drive or physiology drive, for examples feeling of hungry. Secondary motivation depends on freewill of people itself because different people have different drive and motive.

According to Ahmad (2009), Islamic motivation needs theory consisting of four components, such as 1) drive, 2) instinct and innate biological, 3) incentives and 4) commitment. Drive is an arousal state due physiological need. Instinct and Innate biological determines of human behaviour. Incentives is about external stimuli, which is needed some responses. Commitment is about being Ikhlas to accept and to do anything.

Yet, Islamic perpectives are consisting of faith, determination, good deed, and intention. Therefore, understanding motivation in Islamic perspective can contribute to the modelling of the relationship between work motivation with employee and organizational performance from bottom-up to top-down. Islamic motivation emphasizes on reason and process to stimulate human action in order to achieve the needs in life.

\section{Islamic Religious Leaders}

Islamic religious leaders have traditionally been people who as part of the clerisy, mosque, or government, performed a 
prominent role within their community or nation.

Religious leadership may take a variety of non-formal shapes. Yet, Islamic religious leadership is based on Qur'an, Prophet, Wise caliphs, and Pious Followers. Islamic religious leadership are contained of faith, struggle, knowledge seeking, piety, charity, decision making, and others.

As Qur'an advice, being an Islamic religious leader must follow from Prophet Muhammad footsteps. He was the greatest leader in the universe. $\mathrm{He}$ has Islamic leadership, which is considered as an Amanah (a trust) and a responsibility. He required to meet Allah obligations to lead Islam followers. Besides that, Prophet Muhammad also had Siddiq, Fatonah, and Tabliq.

Siddiq means about being honest, true, and truthfulness. Tabliq means being responsive clearly and delivering message as clear as the truthfulness. Amanah means being trusted and responsibility. Fatonah means being knowledgeable and mentoring the knowledge to his followers.

Those Rasulullah Leadership can be followed to reach the goal and to maintain peacefulness in the environment, especially in Muhammadiyah 3 waru Junior HighSchool.

In other words, The Islamic leadership is also known as Prophetic Leadership, because the best leadership is following Rasullulah S.A.W according to Qur'an.

\section{E. CONCLUSION}

This research is expected to contribute to scientific development and can also be a reference for other researchers. The success of this study is largely determined by many factors in environment that occurs in the research field such as the character of the individual led, team work, work environment, local culture, group personality, and time owned by the school.

This research promotes Islamic leadership motivation that is within the Muhammadiyah 3 Waru Junior HighSchool environment which is demonstrated by the teachers. This motivation only appears in positive motivation and self-inner motivation. The positive motivation of the teachers is seen by being a host who is responsive in providing information, attention, cooperation, participation, and responsibility to the school. This motivation always presents better discourses or actions such as high morale, discipline in carrying out tasks, having very good self-confidence, and being organized according to the work task.

Thus has similarity as what is in the message of Allah S.A.W so that it becomes 4 keys to be success that is equivalent to leadership strengths namely Inspiration Strength, Motivation Power, Solution Power, and Predictive Strength. In addition there are several ways to increase the motivation of Islamic leadership as follows, respect, information, behavior, punishment, orders or commands, and feelings or sense.

Giving fair respect can be an appreciation for work performance, rank, experience, and so on. Providing information to colleagues can convey various explanations for work mistakes so that they can improve their performance. Seeking good behavior can be an example for colleagues to change their behavior for the better.

Giving a warning is part of the effort to give a punishment in order to minimize the defeat for the next time. Giving orders or commands to colleagues should use indirect orders, in order to minimize the occurrence of disputes in the work environment. That commands must be in invitation command forms and can be start by giving an example first.

Interaction with colleagues is an interaction between humans. Humans are soulful people. This manner should need to understand how the hopes and feelings that are within them. The feeling is a sense of belonging, participate, unity, friendliness, being accepted in the group, and a sense of accomplishment.

Interaction of Islamic is focusing in social interaction based on Qur'an and Hadist 
guidelines. The guidelines are dividing into some general rules, such as 1) maintaining tie with one's relations (called as silaturrahim) is obligatory upon Muslims and severing those ties (qat'urrahim) is one of the major sin; 2) severing ties is causing distress to the parents whom Almighty Allah has enjoined kindness and compassion and being kind to one's parents; 3) respecting the elders; visiting one another; 4) being truthfulness; 5) being in acquaintances and friends with non Muslims; 6) enjoining good and forbidding evil are obligatory; 7) improving kindness towards people; 8) making peace between people; 9) giving sincere advice for Muslim brethren; and 10) involving charity for the sake of Allah.

Those rules are always being follow for every Muslim in the world and must be done as an obligatory worship for Allah to gain bless and pahala.

Being a leader is an ideal worker and has primary assets of an ideal worker such as knowledge of Qur'an and Hadist; Iman or Faith; Taqwa or consciousness; A'mal or deeds; Salah or prayer; du'a or supplication; infaq or spending in the way of Allah; voluntary fasting; and others.

Islamic motivation is needed for every Muslims in the world. Motivation itself can define as the desire within an individual that stimulates human to do an action. Motivation is the process to determine the intensity, direction, and the provisions of the individual's in achieving a goal or a target.

In the end, Islamic leadership motivation must be used in school in order to built better environment that can give better life, option, solution, and thought for the Muhammadiyah 3 Waru Junior HighSchool residents. Thus can develop the Muhammadiyah 3 Waru Junior HighSchool more well-known in society and can be trust by the society to send their children to join with the school.

Yet, Islamic motivation is needed for every Muslims in the world. Motivation itself can define as the desire within an individual that stimulates human to do an action. Islamic perpectives are consisting of faith, determination, good deed, and intention. Therefore, understanding motivation in Islamic perspective can contribute to the modelling of the relationship between work motivation with employee and organizational performance from bottom-up to top-down. Islamic motivation emphasizes on reason and process to stimulate human action in order to achieve the needs in life.

Besides, Islamic leadership itself is a person or a group that will lead humanity from the brink of destruction to the way of Allah the Almighty. Importances of Islamic leadership are 1) every movement has a need for leadership; 2) similar to the engine of a train; 3) can solve the problems of humanity.

Being a leader can lead someone else by motivating them to strive for certain goals rather than simply act on orders. The leader tries to create a safe and trusting environment, and ensure the organization is positioned for success in its domain.

Being a motivational leader in Muhammadiyah 3 Waru Junior HighSchool needs a good qualified leader and a high motivation, especially to lead students who are lacking in Islamic knowledge and Islamic behaviour.

Based on the statement above, AlQur'an also says about motivational leadership is known as Imam. Imam means leader or guide, was given to Prophet Ibrahim A.S. Being an Imam has came after some tests, it was not simply given, but earned. It is prooven in Surah Al-Anbiya verse 73:

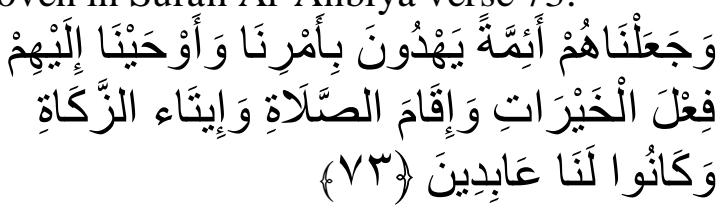

Means that: And We made them leaders, guiding by Our command; and We inspired them to do good works, and to observe the prayer, and to give out charity. They were devoted servants to Us. 
Based on that verse, becoming Islamic motivational leadership must be followed with Islamic knowledgeable, agreement in the management, and teamwork in the school.

Without those three concepts, a leader cannot use his or her effort clearly and professionaly. Then Islamic motivational leadership is also known as Prophetic Leadership, because the best leadership is following Rasullulah S.A.W, which mention in Al-Qur'an.

\section{REFERENCES}

\section{Book}

Adz-Dzakiey, Hamdani bakran. 2005. Prophetic Intelligence - Kecerdasan Kenabian. Yogyakarta: Islamika.

Arep, Ishak dan Tanjung. 2003. Manajemen Motivasi. Jakarta: PT. Gramedia Widiasarana Indonesia.

Hakim, Abdul. 2007. Kepemimpinan Islami. Semarang: Unissula Press.

Hoy, Wayne. K and Cecil G. Miskel. 2013. Educational Administration: Theory, Research, and Practice. Mc Graw Hill.

Kuntowijoyo, A.E. Priyono. 1991. Paradigma Islam: Interpretasi untuk Aksi. Bandung: Mizan.

Sardiman, A.M. 2004. Interaksi \& Motivasi Belajar Mengajar. Jakarta: PT Raja Grafindo Persada.

Tim Dosen Administrasi pendidikan. 2013. Manajemen Pendidikan. Bandung: Alfabeta.

\section{Papers}

Khair, Z. 2014. Pembelajaran Arah Diri dalam Pembelajaran Dewasa dan Peranan Motivasi Keagamaan. (Ph.D
Thesis). Faculty of Management, Universiti Teknologi Malaysia.

\section{Article Journal}

Ather, S.M, Khan, M.A, \& Hoque, N. 2011. Motivation as conceptualised in traditional and Islamic management. Humanomics, Vol. 27(2): Pp. 121-137.

Babbie, Earl (2014). The Basics of Social Research (6th ed.). Belmont, California: Wadsworth Cengage. pp. 303-04.

Baharun, Hasan. 2017. Peningkatan Kompetensi Guru Melalui Sistem Kepemimpinan Kepala Madrasah AtTajdid. Jurnal Ilmu Tarbiyah, Januari,Vol. 6 No. 1.

Desky, Harjoni. 2014. Pengaruh Etos Kerja Islami dan Gaya Kepemimpinan Terhadap Kinerja Karyawan Rumah Makan Ayam Lepas Lhoksumawe. INFERENSI, Jurnal Penelitian Sosial Keagamaan, Desember, Vol. 8, No. 2.

Hambal, Muhammad. 2018. Halaqah Tradition in Building Rabbani Characters in Pesantren Al-Islam Lamongan, East Java, Indonesia. Jurnal Studia Religia, Vol. 2, No. 1

Malik, Abdul dan Untung Sriwidodo. 2013. Pengaruh Motivasi Kerja dan Kedisiplinan terhadap Kinerja Guru SMA Assalaam Surakarta dengan Kepemimpinan Kepala Sekolah sebagai variabel moderasi. Jurnal Manajemen Sumberdaya Manusia, Juni, Vol. 7 No. 154, Hlm. 53 - 66.

Usman, H. \& Raharjo, N.E. 2013. Strategi Kepemimpinan Pembelajaran Menyongsong Implementasi Kurikulum 2013. Jurnal Cakrawala Pendidikan, Th. XXXII (1), Hlm. 1-13. 